\title{
CHANGES IN PIG CERVICAL MUCUS IN RELATION TO THE OESTROUS CYCLE
}

\author{
N. B. HAYNES \\ University of Nottingham School of Agriculture, \\ Sutton Bonington, Loughborough, Leicestershire
}

(Received 19th November 1970)

\begin{abstract}
Summary. Daily or more frequent samples of cervical mucus were collected from forty-two gilts and analysed for $\mathrm{Na}$ and $\mathrm{K}$. In five gilts, sampled through several oestrous cycles, the $\mathrm{K}$ level exceeded that of $\mathrm{Na}$ for short periods during oestrus. The ovarian status of twenty animals indicated that the $\mathrm{K}$ peak occurred approximately $40 \mathrm{hr}$ before ovulation but with some individual variations. Two of these animals did not show a $\mathrm{K}$ peak, and had never ovulated. The results differed in twelve gilts on a restricted feed level, the $\mathrm{K}$ level generally being in excess of $\mathrm{Na}$. A $\mathrm{K}$ peak occurred in two immature gilts after injection of deoxycorticosterone.
\end{abstract}

\section{INTRODUCTION}

Numerous studies have indicated that changes in the properties of human cervical mucus, particularly arborization patterns, are under hormonal control (cf. Ullery, Livingston \& Abou-Shabanah, 1959; Simmons, 1965). Extensions of these studies demonstrated that reducing substances increase in the cervical mucus of women at ovulation (Birnberg, Kurzrok \& Laufer, 1958), a peak in the $\mathrm{Na}$ content of dry cervical mucus occurs at ovulation (Herzberg, Joel \& Katchalsky, 1964) and an increase in chloride content is also coincident with ovulation (McSweeny \& Sbarra, 1967). In farm animals, arborization peaks, corresponding to those in the human, occur around oestrus in cows (Alliston, Patterson \& Ulberg, 1958), sheep (Raeside \& McDonald, 1959) and sows (Betteridge \& Raeside, 1962), but variability in relation to the time of ovulation is greater than in the human. Similarly, the content of reducing substance in the cervical mucus of cattle (Bane \& Rajakoski, 1961) and pigs (Polge, 1960; Betteridge \& Raeside, 1962) shows marked variability.

Definitive changes take place in the composition of uterine secretions throughout the oestrous cycle in the rat, rabbit, sheep and cow, and studies on castrates indicate that the composition is under hormonal control (Heap, 1962; Heap \& Lamming, 1962). Similar changes occur in uterine secretions during the oestrous cycle of the intact pig (Haynes \& Lamming, 1964). It was considered that these changes may be reflected in cervical mucus, a material relatively easy to sample, and could give a chemical method of estimating endocrine status if the inherent variability were small. This paper describes 
changes in the $\mathrm{Na} / \mathrm{K}$ ratio of cervical mucus from the pig around the time of ovulation. The possible relationship to known hormonal changes occurring at this time is considered.

\section{MATERIALS AND METHODS}

\section{Animals and treatments}

Large White $\times$ Landrace gilts, initially weighing about $85 \mathrm{~kg}$, were used. They were housed in groups of five, fed a pelleted sow ration and given unlimited water. No attempt was made to monitor the uptake of $\mathrm{K}$ and $\mathrm{Na}$. The daily quantity of feed depended on the particular experiment. Animals were examined before mucus collection for reddening and swelling of the vulva. After mucus collection, the animals were tested for oestrous behaviour by the haunch pressure test, or with a boar which was not allowed to mate.

\section{Collection and analysis of cervical mucus}

Animals were fed in individual feeders between 09.00 and 10.00 hours each day and mucus was collected during this time once daily unless otherwise stated. No restraint other than the feeders was necessary. Tubing and vessels for mucus collection were washed several times with deionized water and dried at $80^{\circ} \mathrm{C}$ before use. The vulva was wiped with Dettol cream, dried, and a polythene tube (external diameter $1.5 \mathrm{~cm}$; internal diameter $0.8 \mathrm{~cm}$ ) was inserted into the vagina as far as possible. A smaller polythene tube was passed through this until it could be inserted no further and a negative pressure applied by gentle suction. A small amount of mucus ( 2 to $5 \mathrm{mg}$ ) usually accumulated in the cervical end of this tube, but occasionally, especially during oestrus, several $\mathrm{ml}$ of mucus were collected. The tube was removed, the mucus transferred to a small plastic-stoppered glass vial and determinations carried out within $2 \mathrm{hr}$. The outside of the vial was rinsed with deionized water, the stopper removed and the whole vial transferred to a tube containing $10 \mathrm{ml}$ of deionized water which was agitated for $10 \mathrm{~min}$. Determination of $\mathrm{Na}$ and $\mathrm{K}$ were made on the solution using an EEL flame photometer and appropriate standards.

\section{Experiment 1. Cervical mucus studies in normal gilts}

Five gilts given $2 \cdot 2 \mathrm{~kg}$ of feed/day were used and cervical mucus samples were collected over four or five oestrous cycles. The animals were slaughtered at convenient times and the ovaries examined for recent ovulations.

\section{Experiment 2. Cervical mucus studies from gilts synchronized with methallibure}

Three normally cycling gilts were given $1.8 \mathrm{~kg}$ of feed each day to which had been added $100 \mathrm{~g}$ maize meal pre-mix made from $2 \mathrm{~kg}$ 'Aimax' ( $1 \%$ methallibure (ICI 33,828) in talc) mixed with $20 \mathrm{~kg}$ maize meal. After 20 consecutive days, the pre-mix was discontinued. Pregnant mares serum (750 units FsH activity in $5 \mathrm{ml}$ distilled water) was injected subcutaneously at 09.00 hours on Day 21 and HCG (500 units of LH activity in $5 \mathrm{ml}$ distilled water) intramuscularly at 09.00 hours on Day 25 . Mucus samples were taken every $6 \mathrm{hr}$ on the day of HCG injection. 
Experiment 3. Cervical mucus studies and examination of ovarian status

Twenty gilts fed $1.8 \mathrm{~kg} /$ day were used and daily collection of mucus was carried out for 25 to 40 days. The animals were slaughtered at times from 0 to $50 \mathrm{hr}$ after the occurrence of a $\mathrm{K}$ peak at the second oestrous period. The ovaries were examined visually for fresh corpora lutea and the average diameter of follicles larger than $3.0 \mathrm{~mm}$ was recorded after fixing the ovaries in formol saline and cutting into $1 \cdot 0-\mathrm{mm}$ sections.

In four animals, mucus samples were collected at 06.00, 09.00, 12.00, 16.00 and 21.00 hours daily from 2 days before the expected occurrence of a $\mathrm{K}$ peak, until slaughter. These animals were given $500 \mathrm{~g}$ of food on each occasion to facilitate mucus collections.

Experiment 4. Cervical mucus studies in underfed gilts

Twelve gilts were fed $1.4 \mathrm{~kg}$ per day and mucus collected for 20 to 30 days.

Experiment 5. Cervical mucus studies in gilts given deoxycorticosterone

Samples of mucus were collected for 9 days from two immature gilts initially weighing $80 \mathrm{~kg}$ and fed $2 \cdot 2 \mathrm{~kg} /$ day. An intramuscular injection of deoxycorticosterone (50 mg in $5 \mathrm{ml}$ arachis oil) was given at 10.00 hours on Days 9 and 11 . Additional mucus samples were collected at 14.00 hours on Days 1 and 11 .

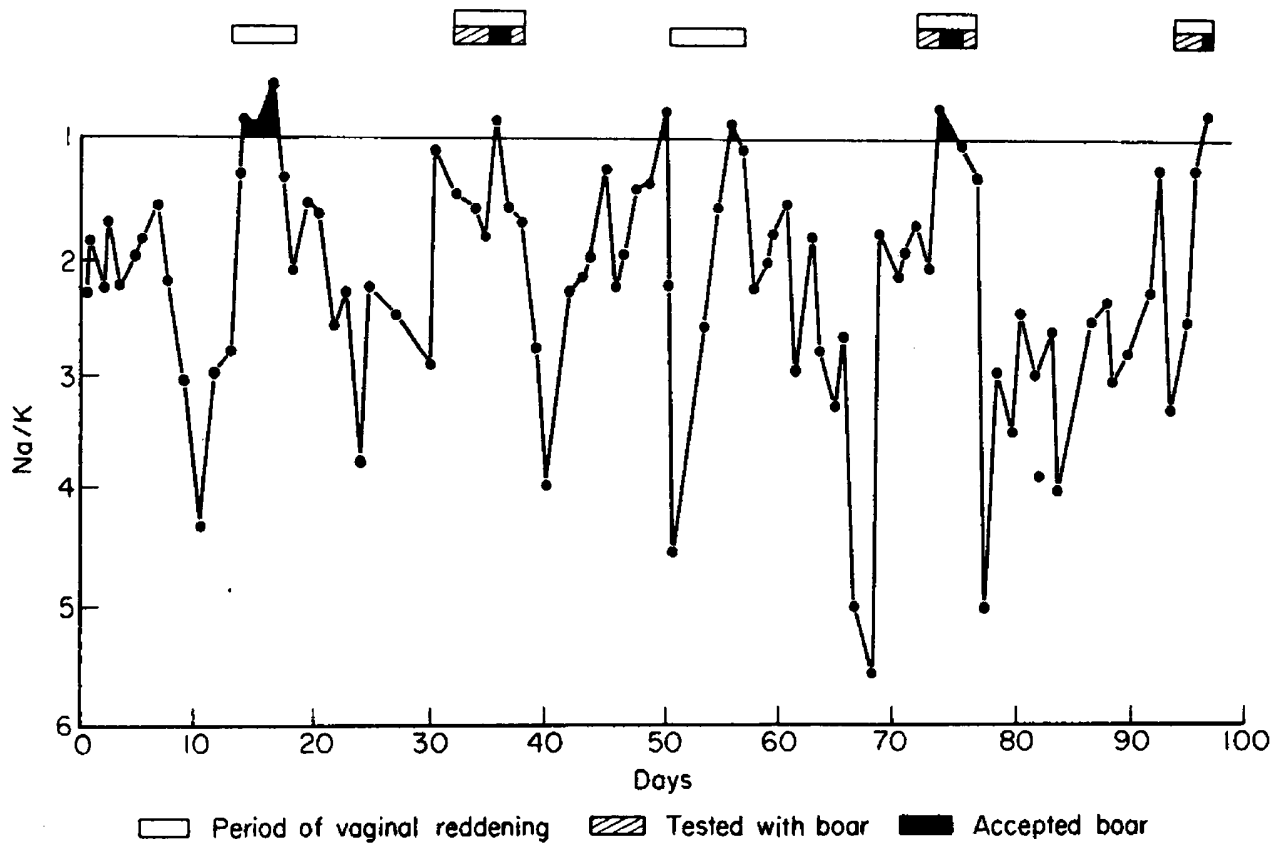

TExT-FIG. 1. Ratios of $\mathrm{Na} / \mathrm{K}$ in daily samples of cervical mucus collected from one gilt (Pig 488) for 100 days.

Experiment 1

\section{RESULTS}

The daily $\mathrm{Na} / \mathrm{K}$ ratios for one pig are shown in Text-fig. 1 . The other four results were similar. There was a wide variation in $\mathrm{Na} / \mathrm{K}$ ratio, but the amount 
of $\mathrm{K}$ only exceeded that of $\mathrm{Na}$ during oestrus. Occasionally, a twin peak occurred during the period of vulval reddening. All animals were killed within 5 days after a $\mathrm{K}$ peak and all ovaries contained corpora lutea and corpora albicantia.

\section{Experiment 2}

Results are shown in Text-fig. 2. There was an immediate rise in $\mathrm{K}$ following
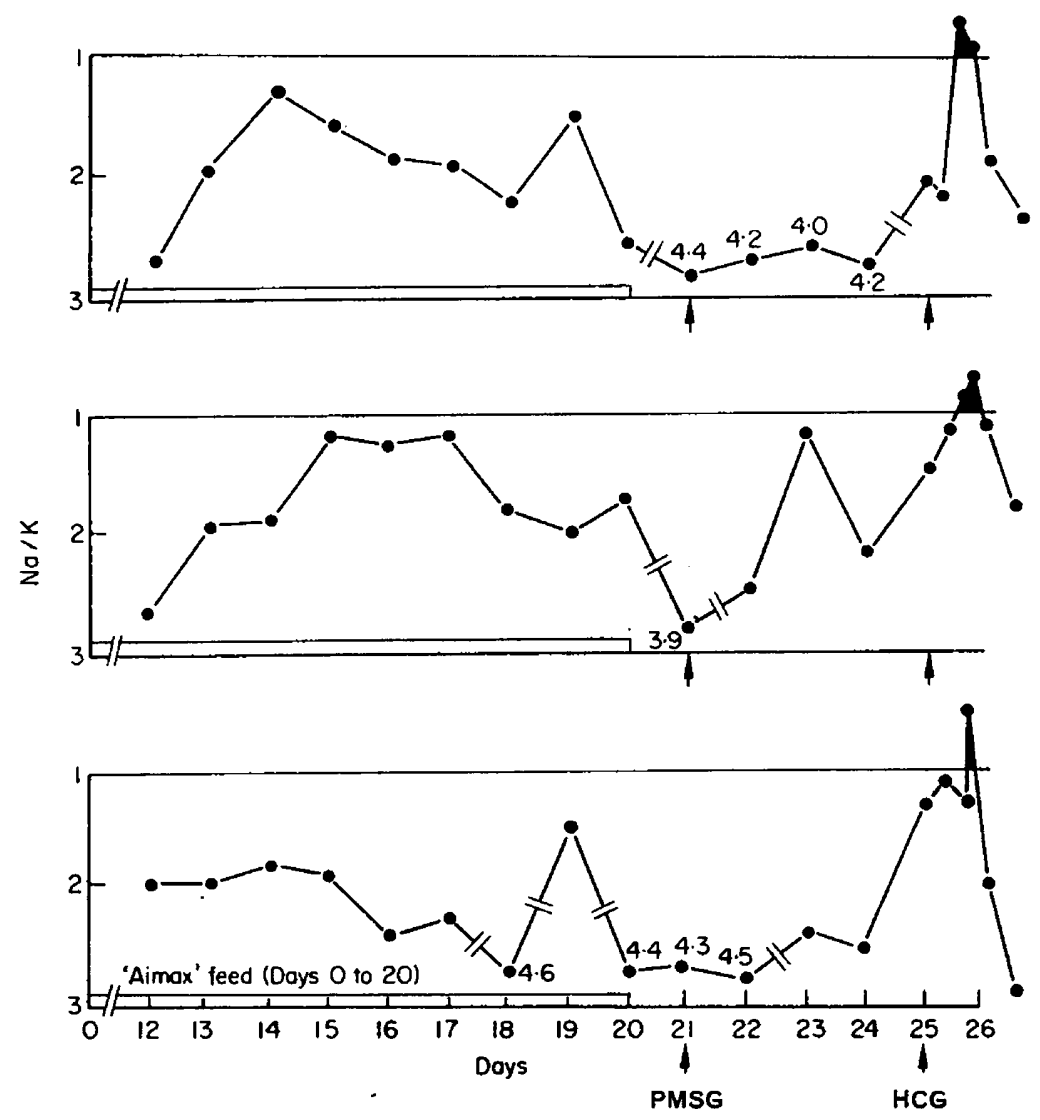

TExT-FIG. 2. Ratios of $\mathrm{Na} / \mathrm{K}$ in samples of cervical mucus collected from three gilts in which ovulation was synchronized with 'Aimax'.

HCG injection, with a K peak on the day of injection which lasted 12 to $16 \mathrm{hr}$. This was synchronous in all three animals.

\section{Experiment 3}

Text-figure 3 shows representative examples of cervical mucus studies. Seventeen pigs had regular $\mathrm{K}$ peaks as depicted by Type 1. At slaughter, all seventeen animals had signs of previous ovulations. Two pigs, depicted by Type 2 , did not show a $\mathrm{K}$ peak and had never ovulated. One pig showed a distinctly different pattern (Type 3 ) and the $\mathrm{K}$ level was above that of $\mathrm{Na}$ for the majority of determinations. This animal had pronounced behavioural differences 
compared to others; it was extremely nervous and objected violently to the collection of cervical mucus. In the four animals in which mucus was collected
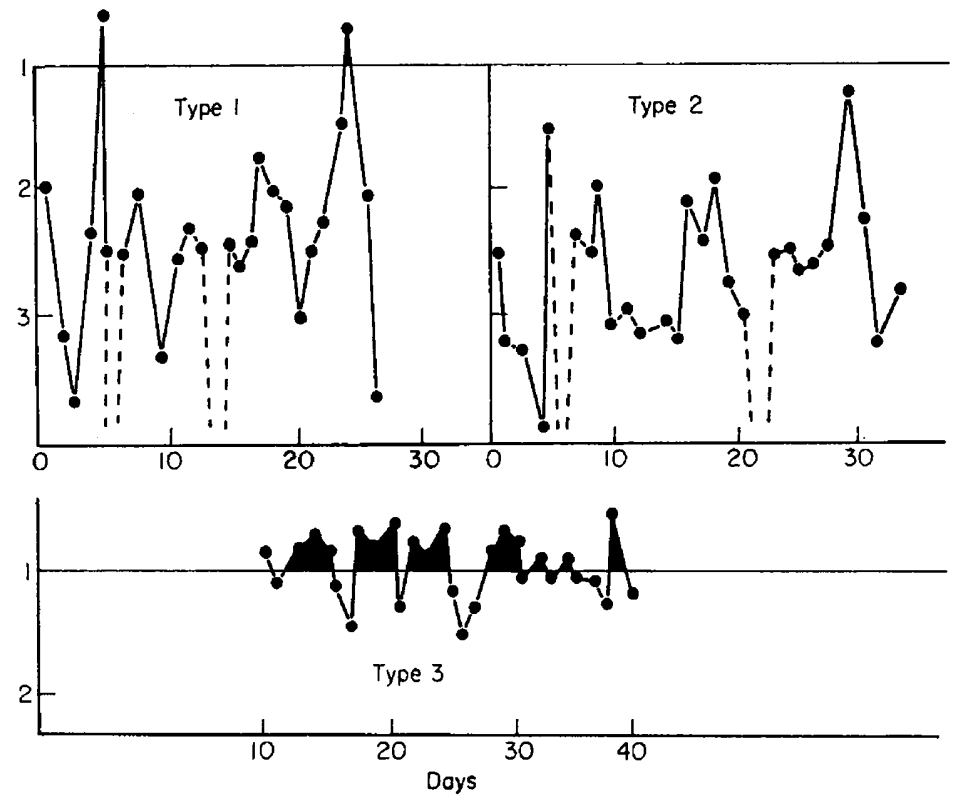

TEXT-FIG. 3. Representative $\mathrm{Na} / \mathrm{K}$ ratios in samples of cervical mucus collected from twenty gilts over 20 to $\mathbf{4 0}$ days. Seventeen animals were represented by Type 1, two by Type 2 and one animal was represented by Type 3.

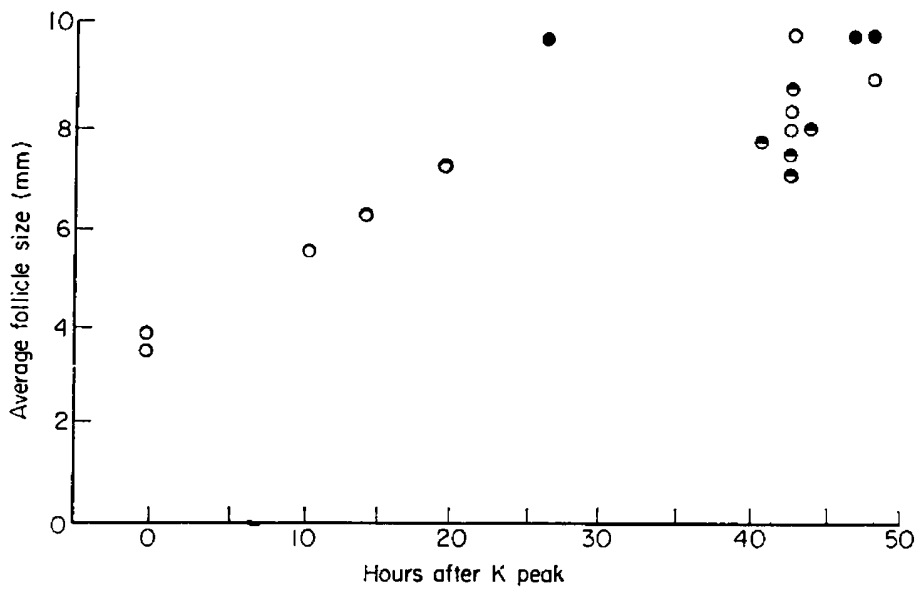

TEXT-FIG. 4. Average size of follicles (O) larger than $3 \mathrm{~mm}$ from seventeen animals slaughtered at various times after a $\mathrm{K}$ peak. Ovulated follicles $(\circlearrowleft)$ are given an arbitrary value of $10 \mathrm{~mm}$, the size of the largest unovulated follicle found. In ovaries containing both ovulated and unovulated follicles $(\theta)$, only the latter are included in the measurement.

four times daily, estimates for the maximum period of the $\mathrm{K}$ peak were 6 to $15 \mathrm{hr}$. The first indications of a peak were always at 09.00 hours.

Average follicle diameter plotted against hours after the first occurrence of a $\mathrm{K}$ peak is shown in Text-fig. 4. There was a trend for an increase in follicular 

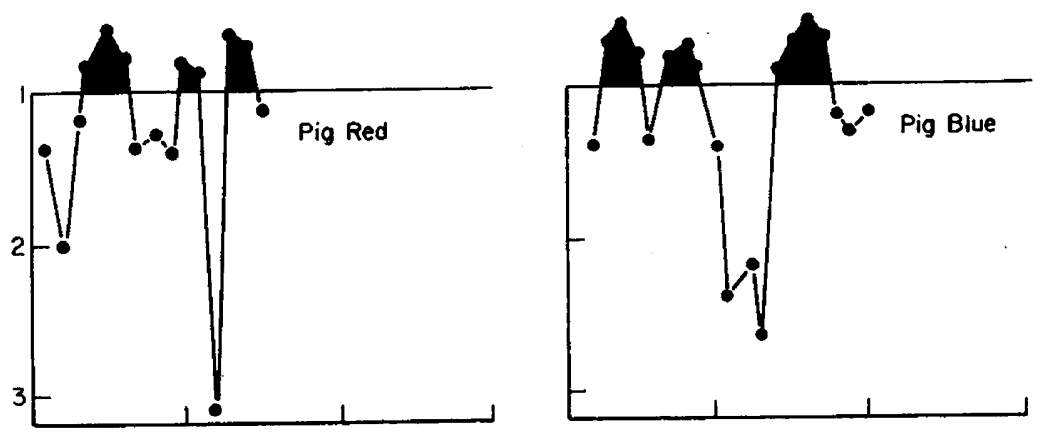

ำ
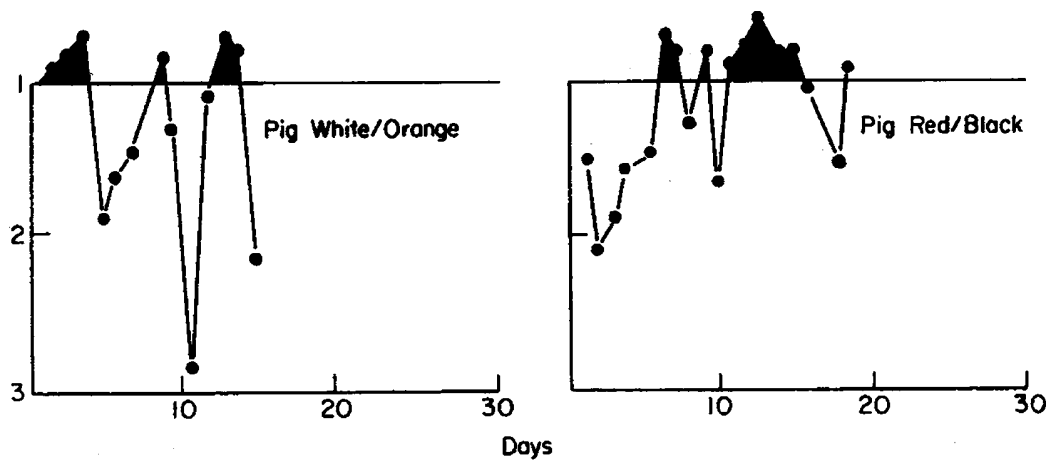

TeXT-Fig. 5. Typical Na/K ratios from daily samples of cervical mucus from underfed gilts.
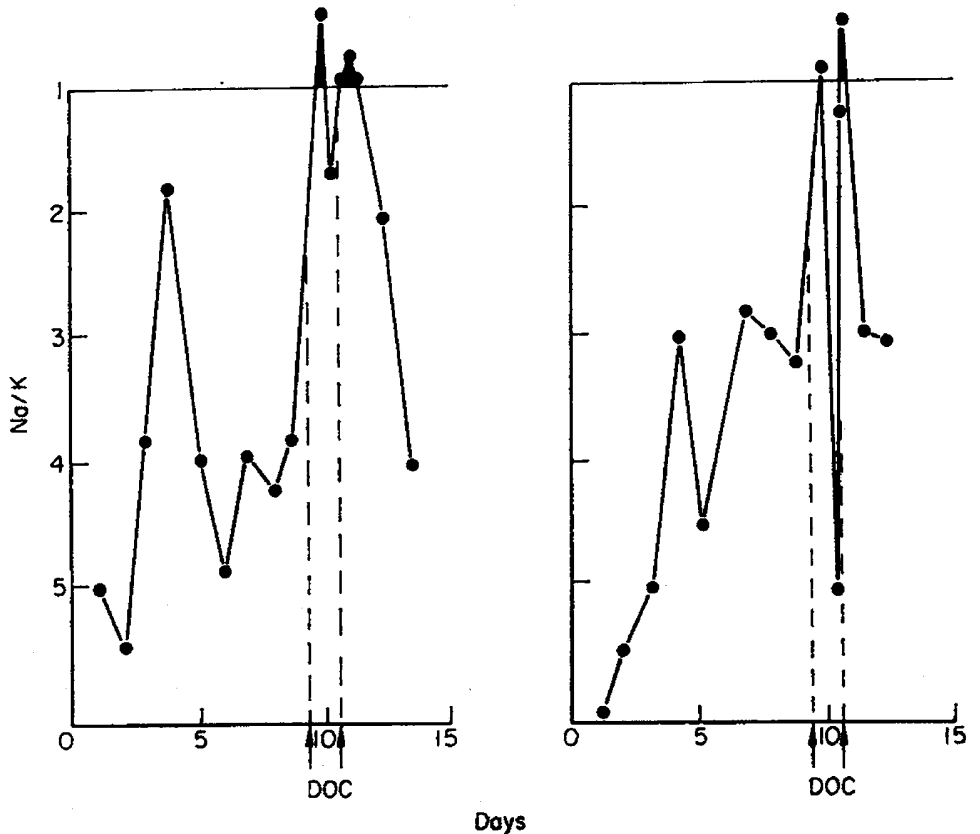

TexT-Fig. 6. Ratios of $\mathrm{Na} / \mathrm{K}$ in two immature gilts given intramuscular injections of deoxycorticosterone. 
size from $0 \mathrm{hr}$ to $40 \mathrm{hr}$, with a number of animals in the process of ovulation at this time. However, one animal had ovulated by $25 \mathrm{hr}$ and one had no signs of ovulation by $50 \mathrm{hr}$.

\section{Experiment 4}

Typical results are shown in Text-fig. 5 . The $\mathrm{K}$ level relative to $\mathrm{Na}$ was much higher than that found in normal gilts, with $\mathrm{K}$ peaks occurring frequently.

\section{Experiment 5}

The results are shown in Text-fig. 6 . In each case, injection of deoxycorticosterone caused a transient $\mathrm{K}$ peak.

\section{DISGUSSION}

The results indicate that, in the normal gilt, there are cyclic changes in the $\mathrm{Na} / \mathrm{K}$ ratio of cervical mucus during the oestrous cycle, with the $\mathrm{K}$ content exceeding that of $\mathrm{Na}$ for a period just before ovulation. These findings are in accord with urinary $\mathrm{Na} / \mathrm{K}$ measurements in the rat (Pye \& Matty, 1968). There is an inherent variability, in the length of time for which the $K$ peak occurs (estimated at 6 to $16 \mathrm{hr}$ ) and, moreover, there is some variability in terms of the time of ovulation after the onset of the $\mathrm{K}$ peak, two animals out of seventeen examined showing marked variations from the normal pattern (see Text-fig. 4).

The occurrence of the $\mathrm{K}$ peak concurrent with the time of highest urinary oestrogen excretion as reported by Raeside (1963) suggests a possible relationship between $\mathrm{Na} / \mathrm{K}$ and oestrogen secretion. If this is so, the variability in terms of the $\mathrm{K}$ peak in relation to ovulation may be explained since there is also variability in the time of high oestrogen excretion, at least in relation to the time of onset of oestrus. However, the rise in urinary excretion takes place over several days whilst the change in $\mathrm{Na} / \mathrm{K}$ ratio is of comparatively short duration. A further possibility that the $\mathrm{Na} / \mathrm{K}$ ratio is influenced by LH release is suggested by the closeness of $\mathrm{K}$ peak onset with HGG injection (Exp. 2). Furthermore, the relationships with regard to both time of onset and duration of LH release (Niswender, Reichert \& Zimmerman, 1970) are good.

The anomalous results with animals on a severely restricted feed intake may be due to stress since the results are similar to the one animal in Exp. 3 which was highly nervous. Increased adrenocorticosteroid output associated with this type of condition would certainly favour increased $\mathrm{K}$ excretion. Animals on a restricted feed allowance are also more difficult to handle and the stress associated with underfeeding may result in an enhanced adrenocorticosteroid output. It is also possible that the transient decrease in $\mathrm{Na} / \mathrm{K}$ ratio before ovulation in the normal animal may be mediated through the adrenal cortex since there are reports of an adrenal-ovarian axis where adrenal function is controlled or influenced by oestrogen production (Fonzo, Mins \& Nelson, 1967). In this context, the first evidence for $\mathrm{K}$ peak occurrence was at 09.00 hours; a time associated with heightened adrenocorticosteroid secretion in other species (Diraimondo \& Forsham, 1956; Ney, Shimizu, Nicholson, Island \& Liddle, 1963). Further evidence for adrenal implication was found in the preliminary 
Exp. 5, where the results were simulated by treatment with deoxycorticosterone. In the rat, the adrenal appears to participate in the timing of LH release (Nequin \& Schwartz, 1971).

\section{ACKNOWLEDGMENTS}

This investigation was supported by the Pig Industry Development Authority. The author is indebted to Mrs Ann Cooper and Mrs Carol Bradfield for technical assistance and to ICI Ltd for providing the 'Aimax'.

\section{REFERENGES}

Alliston, G. W., Patterson, T. B. \& Ulberg, L. C. (1958) Crystallization patterns of cervical mucus as related to oestrus in beef cattle. F. Anim. Sci. 17, 322.

Bane, A. \& Rajakoskr, E. (1961) The bovine oestrous cycle. Cornell Vet. 51, 77.

BETTERIDGE, K. J. \& RAESIDE, J. I. (1962) Investigation of cervical mucus as an indicator of ovarian activity in pigs. 7 . Reprod. Fert. 3, 410.

Birnberg, C. H., Kurzrok, R. \& Laufer, A. (1958) Simple test for determining ovulation time. 7. Am. med. Ass. 166, 1174.

Diraimondo, V. G. \& Forsham, P. H. (1956) Some clinical implications of the spontaneous diurnal variation in adrenal cortical secretory activity. Am. J. Med. 21, 321.

Fonzo, D., Mrns, R. B. \& Nelson, D. H. (1967) Estrogen influence on pituitary and adrenal function. in the rat. Endocrinology, 81, 29.

Haynes, N. B. \& Lamming, G. E. (1964) Studies on the uterine secretion of the pig. $V^{\circ}$ Congresso internazionale per la riproduzione animale e la fecondazione artificiale, 2, 335.

HeAp, R. B. (1962) Some chemical constituents of uterine washings: a method of analysis with results from various species. F. Endocr. 24, 367.

Heap, R. B. \& Lamming, G. E. (1962) The influence of ovarian hormones on some chemical constituents of the uterine washing of the rat and rabbit. 7. Endocr. 25, 57.

Herzberg, M., Joel, C. A. \& Katchalsky, A. (1964) The cyclic variation of sodium chloride content in the mucus of the cervix uteri. Fert. Steril. 15, 684.

McSweeney, D. J. \& Sbarra, A. J. (1967) Pregnancy test using cervical mucus. Fert. Steril. 18, 866.

Nequin, N. G. \& Schwarz, N. B. (1971) Adrenal participation in the timing of mating and LH release in the cyclic rat. Endocrinology, 88, 325.

Ney, R. L., Shimizu, N., Nicholson, W. E., Island, D. P. \& Limdle, G. W. (1963) Correlation of plasma AGTH concentration with adrenocortical response in normal human subjects, surgical patients and patients with Cushing's disease. F. clin. Invest. 42, 1669.

Niswender, G. D., Reichert, L. E. \& ZnMmerman, D. R. (1970) Radioimmunoassay of serum levels of luteinizing hormone throughout the estrous cycle in pigs. Endocrinology, 87, 576.

Potge, G. (1960) Observations on cervical mucus. F. Reprod. Fert. 1, 113.

PYE, R. G. \& MATTY, A. J. (1968) Cyclic variations of the urinary Na:K ratio in female rats fed on a 'low iodine' diet. 7. Endocr. 40, x.

RAESIDE, J. I. (1963) Urinary oestrogen excretion in the pig at oestrus and during the oestrous cycle. 7. Reprod. Fert. 6, 421.

Raeside, J. I. \& McDonald, M. F. (1959) Arborization of cervical mucus in the ewe. F. Endocr. 18, 350.

Simmons, G. A. (1965) Gervical mucus. Proc. R. Soc. Med. 58, 908.

Uliery, J. G., Lrvingston, N. \& Abou-Shabanah, E. H. (1959) The mucus fern phenomenon in the cervical and nasal smears. Obstet. gynec. Surv. 14, 1. 